\title{
INTERNAL ADVISORY SERVICES IN EDUCATION: INFLUENCE AND CONTRIBUTIONS IN PORTUGUESE HIGHER EDUCATION INSTITUTIONS
}

\author{
S. Balau ${ }^{1}$, A. Magalhães ${ }^{2}$, M.L. Branco ${ }^{3}$ \\ ${ }^{1}$ University Beira Interior (PORTUGAL) \\ ${ }^{2}$ University of Porto. Centre for Research in Higher Education Policies (CIPES), Faculty of \\ Psychology and Education Sciences (PORTUGAL) \\ ${ }^{3}$ University Beira Interior (UBI). Centre for Research in Education and Psychology \\ (CIEP - University of Évora) (PORTUGAL)
}

\begin{abstract}
The Public Administration (PA) and the Portuguese public Higher Education Institutions (HEls) have undergone profound changes in recent decades, triggered by aspects such as the massification of higher education and the need to adapt to society's new challenges others. Following an international trend, the Public Administration and the HEls began to tend towards an approximation to the private sector by introducing private management models and practices, with HEls "imitating" business organisations. Such changes took place under the influence of the New Public Management (NGP) current, which was materialised in Portugal in 2007 through the Legal Regime of Higher Education Institutions (RJIES). This legal framework brought greater autonomy to HEls and allowed them to assume the public foundation model of private law. In this context, HEls became more complex organisations, and their actors saw their roles and forms of participation in the organisation's life altered. Such changes led to an increase in the number and specialisation of technical and administrative/nonteaching staff in HEls and changes in the roles and identities of these professionals.

Moreover, if, before, the boundaries between academics and non-academics were well delimited, this is no longer clear. Within the technical and administrative staff, we find professionals who characterised by high autonomy in the performance of their functions, who limited to performing the functions listed in their job description. We find and highlight the Internal Advisory in Education function within this group, being the advisory in education a subject still little studied. These are employees who work very close to management in the HEls, performing support and support for decision-making, contributing with studies, opinions and decision proposals, preparing and influencing decision-making by the legitimate decision-makers. Our objective is to understand how internal advisors influence decision-making in the governance and management of Portuguese public HEls; we will follow a research methodology of qualitative nature. Through multiple case studies, we intend to analyse three HEls - two Universities, one of them with a foundational model, and one Polytechnic Institute. As we found in the literature, the influence of these professionals is growing and central in decision making by policymakers. It is possible to maximise the contribution of these professionals by generating synergies, cooperation and mediation between knowledge and powers.
\end{abstract}

Keywords: Internal Advisory Services, Portuguese Public Higher Education Institutions, Technical and Administrative Staff, Governance, Management.

\section{INTRODUCTION}

In recent decades, public administration has been marked by profound changes, motivated by globalisation, to which Higher Education Institutions (HEls) have not been immune. In order to respond to society's challenges and a massified higher education, public HEls started to tend towards an approximation to the private sector, following market values, as being the organisation's model. Thus, the economic rationality conveyed relegated to the background the social and cultural relevance, calling into question knowledge as a public good ([1]). This trend was materialised with the reforms promoted by the Legal Regime of Higher Education Institutions (RJIES), implemented in 2007 and inspired by the New Public Management (NGP) perspectives, marked by the introduction of private management practices, assuming the governance of HEls as business-type organisations, oriented towards results, efficiency, competition and accountability ([2]). 
Reforms introduced in the HEls by the RJIES, marked by the principles of the NPM, strengthened autonomy and led to restructuring in the models of governance and management, with the centralisation of power at the institutional top, with the Rector (in the Universities) and the President (in the Polytechnic Institutes) now performing managerial functions ([3]). Until then, the collegial model was favoured, with the representation of all the academy bodies, with decision-making power ultimately in the hands of the academics. Since 2007, and with RJIES, academia has seen an increase in the participation of external stakeholders in the HEls' governance bodies, this being one of the essential changes promoted by that diploma ([4], [5], [6]), with, simultaneously, a weakening of collegial bodies and the representativity of academics and students in institutional decision-making ([3]). These changes in the organisational structures of HEls have also brought changes to the professional autonomy of teaching staff, who now consider that there is greater control over their work ([7], [8]).

With the increased complexity in HEls, the technical and administrative staff has been growing in number, skills, competencies, knowledge and specialisations ([9]), and it is within this professional group that we highlight the role of advising in education, a topic that for a long time was almost ignored in terms of study ([10]). These are employees who work very close to management in HEls, performing management technical support functions, advisory specialists who prepare decisions, foresee scenarios and consequences and advise, and influence policy and institutional decision-makers ([11]).

Thus, this article is part of an investigation whose central question is: How does the professional group of internal advisors influence decision-making in the governance and management of Portuguese public higher education institutions?

In the first part of this work, we refer to the conditions at the origin of these changes within Portuguese public HEls, namely the NGP and the emergence of Advisory in public administration. We then address the methodological options and final considerations.

The last decades, strongly marked by globalisation and economic competition, have brought profound changes in public administration. Following an international trend, the public sector, driven by economic competition, began to be managed towards efficiency, excellence, competition, quality and accountability ([2]).

As a result, HEls also felt the need to adapt to the new challenges of society and to the need to respond to a Higher Education with growing demand, so repercussions were felt through the introduction of private management practices, with HEls now essentially being seen as entire organisations ([2], [7]). Following international trends, the changes experienced in HEls stand out above all at the level of autonomy and governance. These changes took place based on the New Public Management (NPM) perspectives and related concepts, such as managerialism ([1]).

As Santiago et al. ([2]) state, the concepts of managerialism, new public management, new managerialism and managerialism, a concept used by Lima ([2]), are broadly equivalent. Managerialism enters public administration due essentially to the idea of reforming the state and public administration, based on dissatisfaction with bureaucracy (cited in [2]). According to the authors, in general, we can define this perspective to import private management techniques to the public sector to increase the efficiency and effectiveness of services.

Even before implementing RJIES, there were already, in the public sector and public HEls, to implement private management models to solve some of Higher Education's problems, such as the lack of financial resources. Under the influence of NGP, HEls came to be seen as business organisations, productoriented, supported by the definition of measurable objectives for teaching and research and focused on efficiency, competition and accountability ([2]).

However, what were the conditions that allowed the installation of managerialism in public administration? Santiago et al. ([2]) state that managerialism found room to establish itself in public administration, partly due to dissatisfaction with the bureaucratic system, but also due to assumptions such as the belief that the market regime and the focus on efficiency allow better adaptation to change, i.e. that "the management models and practices of the private sector are superior to the traditional models of government and management of the public sector" ([2], p.7).

In this way, NGP emerges as a perspective that promotes strategic changes in public services and the Academy and as Amaral states,

"This movement [managerialism] (...) replaces the concept of knowledge as a public good - the old university idea that knowledge should be free and universal - by the concept of commercialisation and private property, which calls into question many of the traditional academic values" ([1], p. 42). 
We follow the argument of Santiago et al. ([2]) in stating that between public and private management, there are fundamental differences in the nature, purposes, values and "the meaning of the services provided by the institutions" (p. 3), whereby in general, public service is not provided to make a profit, and this is one of the main differences between the public and private sectors. Furthermore, the same authors highlight that "Universities have a place apart within the public sector" ([2], p. 3). In this regard, in 2015, UNESCO published a document entitled "Rethinking Education: Towards a Global Common Good?" [12] which is fundamentally based on the idea that Education and knowledge are shared and global goods and, as such, are the world heritage of humanity.

In management supported by the NGP perspective, as Amaral ([1]) tells us, "academics, in turn, lose their status as professionals and are increasingly seen as employees in whom the product of their intellectual labour is the property of the institution that pays their salary" (p. 42). From this perspective, teachers' autonomy and professional conduct are at stake, (almost) becoming understood as service providers, seeing their confidence to run institutions diminished ([1]).

In this framework, tinted by NGP and managerialism, the Legal Regime of Higher Education Institutions (RJIES) was then implemented in Portugal in 2007. This diploma, established by Law no. 62/2007, of 10 September [13], brought significant changes to higher education and its institutions, which saw alterations in the relationships between the various participants, at the various levels, especially at the level of governance of Higher Education and in the way HEls are governed. RJIES increased the autonomy of the institutions with the possibility to adopt "the model of institutional organisation and management that they consider more appropriate to achieve their mission, as well as the specificity of the context in which they are inserted" ([13], article 65 RJIES).

In this legal framework, RJIES was innovative in creating the possibility for HEls to assume the foundational model, constituting themselves as public foundations of private law, allowing public universities and polytechnic institutes greater financial and personnel hiring autonomy, thus evidencing expressions of NGP since it uses private management models. In the foundational model, universities show marked managerial characteristics, such as greater financial and contractual autonomy, being obliged to render accounts, which brings them closer to private management ([3]).

Higher education institutions' autonomy in relation to the state can be defined as the possibility, foreseen by law, for HEls to make and implement their own choices, in the fulfilment of their mission, based on rights and duties, as well as the mode of financing and management of other resources. Under the terms of the law, public HEls have cultural, scientific, pedagogical and disciplinary autonomy. Academic autonomy is foreseen in the statutes of each institution.

In the current configuration of HEls, with the implementation of RJIES, the governing bodies saw the traditional form of governance changed, through the "collegial model of multiple seats of institutional governance" ([6], p. 55), with the representation of the academic community, giving way to external participation in supervisory and governance bodies, in the General Council, and greater responsibility of the executive bodies. It is crucial to define governance, which, as we found in Pedrosa et al. ([6]), is considered "how higher education systems and institutions are organised and managed" (p.41) and the "structures, relationships and processes through which policies for higher education are developed, implemented and reviewed, both at national and institutional levels" (p.41).

As mentioned above, one of the significant changes brought by RJIES was the increase of external stakeholders' participation in the General Council (GC) - "External personalities of recognised merit, not belonging to the institution, with relevant knowledge and experience for the institution" ([13], paragraph c) of article 81(2) of RJIES). However, the concept of stakeholder has long been linked to higher education. As early as 2000, Amaral and Magalhães stated that stakeholder is "person or entity with a legitimate interest in higher education and, as such, acquires some right to intervene" ([4], p. 8). According to these authors, historically, the role of universities has long been to preserve culture and knowledge as public and universal goods, free and exempt from vested interests, this being the basis of the Humboldtian concept of the university. In the words of Amaral and Magalhães ([4]):

"The Humboldtian-Newmanian model is based on the assumption that the more independent universities were from the material interests - economic, social and political - of the society in which the institution is embedded, the better its mission (the pursuit of knowledge as an end in itself, its preservation and its diffusion) would be fulfilled, the state being charged with preserving the independence of the university to protect its national interests and culture" (p. 16).

However, changes introduced in society in recent decades, such as the massification of education, economic competition, the exponential growth of knowledge and its management, and the neoliberal 
theories and policies associated with the idea of an inefficient public sector, led to the idea of the "market" as the salvation of all problems, which has changed the relationships between the State and the university ([4]). With the publication of RJIES, the stakeholders saw their influence strengthened and brought to the academy external beliefs and pressures ([5]), and, from the point of view of the rectors, they prefer to have them as allies, without significant interference in the life of the academy.

With the changes brought by RJIES, the General Council took on the leading role in terms of HEls' highest governing body, which is responsible for monitoring the Rectors', or Presidents', work, specifically "Appreciating the acts of the rector or the president and the management board" ([13], paragraph e) of article 82(1) of RJIES).

Starting from the assumption that one of the essential criteria for classifying a given profession is autonomy, Carvalho and Diogo ([8]) analysed how academics understand that the increase in institutional autonomy, brought about by the influence of NPM and managerialism, also corresponds to an increase in their professional autonomy. Moreover, they found that, if on the one hand, HEls have been given greater autonomy. On the other, this trend has come accompanied by new ways of controlling the work of academics, which calls into question their professional autonomy. According to Carvalho and Videira ([7]), lecturers, technical and administrative staff agree that their autonomy is maintained, despite there being an increase in the administrative control of their work. Veiga et al. ([3]) found that the management of HEls, with the implementation of RJIES, influenced by the NGP, came to remove the academics' centrality regarding the institutions' decision-making processes. This because it opened the door to the principle of appointment in the constitution of the governing bodies that began to include external stakeholders to the institutions in the institutional governance structures.

RJIES reconfigured the management of HEls in Portugal, following market mechanisms, with vertical or top-down regulation systems. In essence, the NGP defends management focused on efficiency and effectiveness, based on private sector management instruments, such as competition for clients (students), the definition of objectives, performance measurement and accountability to the government. In this way, governments ensure the achievement of their objectives and the pursuit of their public policies.

\section{TECHNICAL AND ADMINISTRATIVE STAFF}

Changes within HEls have promoted the creation of new organisational structures, new areas of specialisation - according to Baltaru ([14]), new learning technologies, equality in student admissions and diversity standards and staff recruitment. In this way, HEls have become more hierarchical and specialised institutions, which has driven the development of an increasingly professionalised administrative body. Based on the work of Whitchurch (2004), Baltaru ([14]) also mentions that, for HEls, the emergence of new areas of specialisation and the definition of new roles allowed for adaptation and interaction with partner institutions.

As Dobson ([9]) argues, such changes within HEls have led to a transfer of administrative power to an almost invisible group - the 'non-teaching staff' - or non-teaching personnel, also leading to a redefinition of power relations within institutions ([7]). We now focus on this professional group that Dobson ([9]) calls the 'invisible group', and Szekeres ([15]) the invisible workers, the non-academic staff / general staff, which, according to the authors, constitutes half of the largest workforce in universities and yet is defined by what it is not: non-academic / non-teaching (Szekeres, [15]). The authors also mention that, in general, there is some tension, on the part of academics, towards general staff. On the other hand, Dobson ([9]) mentions that universities would collapse without the specialised work of this range of professionals. Dobson ([9]) and Carvalho and Videira ([7]) share the view that this professional group performs essential management support functions within HEls, and that it has grown in complexity, skills, knowledge and specialisations ([9], [16], [17]).

Although the use of the expression non-academic staff is common, this does not mean that the staff accepts it well. This dissatisfaction is revealed by work on the nomenclature preferences of administrative and technical staff in Australia and the United Kingdom ([18]), which indicates that this professional group perceives the term non-academic staff as pejorative, negative. In this study, several issues were raised, such as the reasons for the negative view of the designation non-academic, of which issues of identity and recognition were highlighted, with non-academic staff being described as 'the forgotten workforce' ([18], p. 463). However, in this work, Sebalj et al. ([18]) conclude that this professional group "wants to define themselves, to be visible, recognised and valued" ([18], p. 469)." 
To respond to the increasing demands of HEls, the professional staff expands and diversifies their roles and professional identity. This is an indicator of the complexity and dynamism of an HEI, far beyond what is presented in organisation charts and job descriptions ([16], [17]). On the other hand, given the growing changes in professional identity, the boundary between academics and non-academics has been blurring. The so-called general staff, whose specialisation and professionalisation have been increasing, have also reconfigured their roles and identities ([16], [17]). According to this author, the traditional boundaries of work between academics and professional staff are no longer well defined. We can observe the emergence of space/territory that combines professionals from the academic and professional domains, and which the author presents as the concept of the third space.

Whitchurch ([19]) refers to this increasingly heterogeneous group of technical and administrative staff who do not perform teaching duties and uses various terms such as: 'manager', 'administrator', nonacademic staff, professional staff, support staff, ... The author uses the term professional managers to define two types of professionals: those who perform generalist roles - such as student services and secretarial functions - and those who perform specialist roles - in services such as finance and human resources.

In order to better characterise the professional staff, and based on their job description, the functional content of careers and organisational charts of the institutions, Whitchurch ([17]) proposes the following classification:

- Limited/circumscribed professionals - work within the boundaries defined in their "job description" (or skills sheet). They possess specialist knowledge but are geared towards standardised and pre-determined production.

- Order-crossing professionals - cross the boundaries of their functional content to take strategic/institutional advantage.

- Unlimited professionals - work in large-scale projects, important for institutional development, tolerate a certain degree of risk and ambiguity, use knowledge and experience from other sectors, are oriented towards innovation and creativity, build new institutional knowledge, and are futureoriented.

- Blended Professionals, because of their hybrid identity (Blended Professionals), and that the author characterises as follows - they work and aggregate knowledge from both domains, professional and academic, they participate, with ownership, in the academic discourse, having a global understanding of the University, promoting the establishment of both internal and external communication networks. These professionals work in multifunctional teams, integrating and collaborating in initiatives that require technical and academic contributions. They develop specialised and interpretative functions, performing some of the previously exclusive tasks to lecturers, such as tutoring students and usually have high academic qualifications such as masters and doctorates.

According to the author, if understood in this way, the nature of the work of professional staff is redefined, and the contribution of this group of professionals is maximised ([17]).

\section{THE ADVISORY}

Within this group, we highlight the role of Advisory in Education, a subject that has long been ignored in terms of study ([10]) and has been gaining more prominence. In the words of Lima ([11]),

(...) "advisory refers, on the one hand, to a certain subalternity of functions (of support, aid or assistance to someone) and, on the other hand, to the power of knowledge, to the advisory competence legitimised in expert terms, i.e., to the status of the expert who studies, outlines scenarios, plans, prepares the decision, advises legitimate policymakers and hierarchical superiors in formal organisations" (p. 118).

According to several authors ([10], [11], [20], [21]), given the origin of the advisory concept in the economic-business field, it appears associated with the provision of specialised services, with consensual technical and scientific legitimacy, both in private organisations and in the public administration. It has been gaining increasing importance given the "power exercised by advisors with the leaders" ([11], p. 119).

As Laage-Thomsen ([22]) states, the sociology of professions has revealed that science and expertise have acquired a prominent role in politics and daily life, which explains the increasing "scientification" of policy advice. In the words of Saint-Martin ([23]), as advisors/consultants hold the power of experts, they 
have become, in this way, powerful political actors because of the direct influence they have on politicians. Lima ([11]) also mentions that advisors are "considered advisory or deliberative experts, from the organisation itself or belonging to another organisation" ([11], p. 123). Underlying this statement are the concepts of the internal advisory and external advisory, respectively. Both have the function of promoting reflection on the situations and help decision-making by the decision/policy agents ([24]). Regarding the concept of internal advisory services, Bexiga ([25]) states that this type of advisory services is carried out by employees committed to the organisation, with critical and independent thinking, and who have a global and systemic vision of the organisation in its entirety.

From the analysis made by Lima ([10], [11]), Segovia ([20], [21]) and Block ([26]), the concept of advisory comprises the notion of competence and specialised knowledge, with:

(...) "a cognitive legitimacy mainly focused on the selection of the most effective and efficient means or resources intending to achieve a given end or objective, but lacking the political legitimacy to make the final decision and to choose between alternative ends or objectives" ([11], p. 118).

For Peter Block ([26]), a consultant/advisor is someone who, by their technical, scientific and interpersonal skills, influences (or can influence) someone who has the power to make decisions. According to the author, this influence occurs in technical support, through studies, surveying problems (and possible solutions), planning, guidance. The consultant/advisor has thus a role of expert and also of executor.

According to Lima ([11]), advisory services cannot be wholly neutral or uncompromised from the political aspect because they influence each other mutually, and "advisory services reveal themselves to be an unavoidable auxiliary means and affirm themselves as an authentic source of animation, promotion and legitimisation of reforms" (p. 122). In turn, the technical and specialised advisory skills are not exempt from the political factor because "(...) they cannot fail to take on specific values, objectives, worldviews and interests" (p. 118).

Although it is the political power that makes the decisions, the initiative does not always come from this quadrant. Sometimes, the issues to be addressed arise from internal advisory services, highlighting technical imperatives, thus influencing the political agenda ([11]). As referred to above, it is up to the technical staff to conceptualise the problems and make their normative framework, presenting opinions and proposals for solutions, which Lima ([11]) calls technical, knowledge and expert power. After that, the issue, or problem, then reaches the decision-makers, who hold the legitimate political power and make the decisions. Finally, and to achieve the measures or solutions approved by the political power, the question or problem comes back to the technical body, to the advisors, who will monitor its implementation, holding the power of execution ([11]). This "path" is now presented schematically, adapted from Lima ([11]):

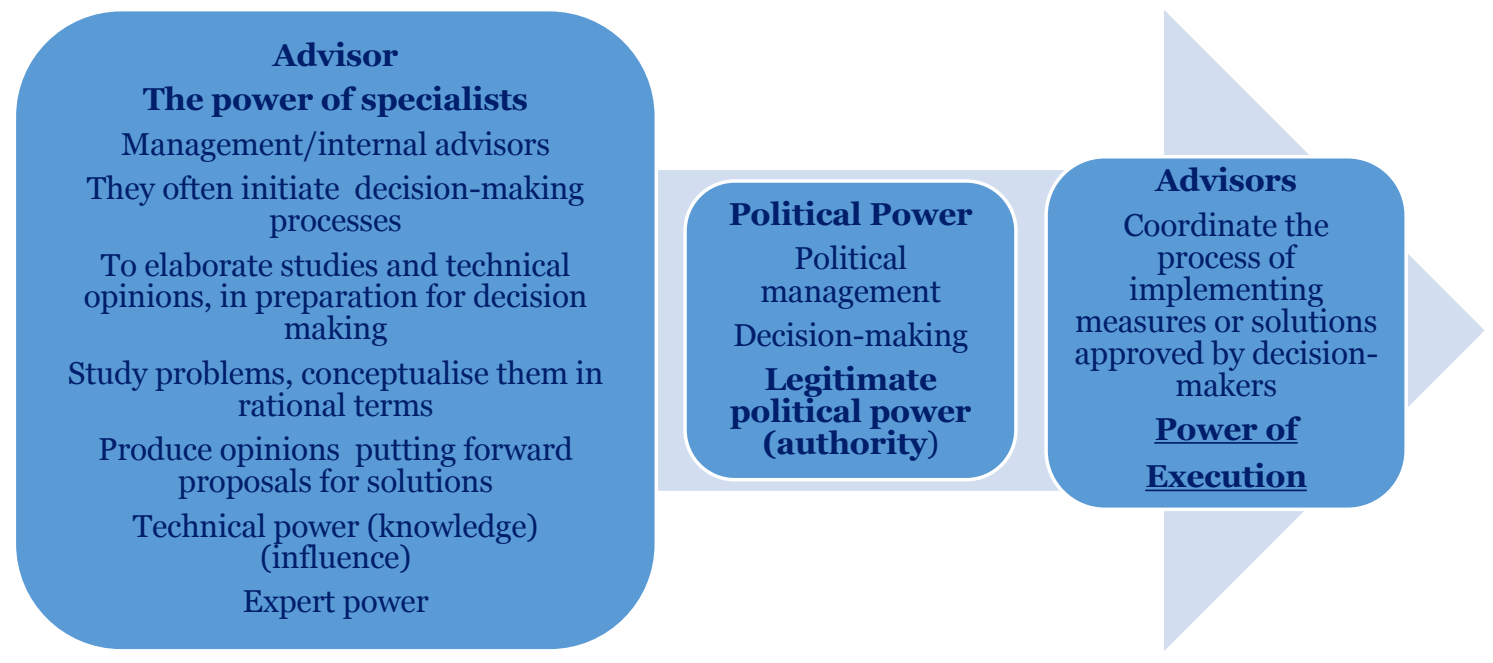

Figure 1 - Decision-making process. Source: Adapted from Lima ([11])

Now, in a scenario inspired by New Public Management, in which HEls are currently inserted, focusing on concepts such as the provision of a service to clients, quality, assessment and auditing, a potential confrontation emerges between political decision-makers, who take decisions, and administrative staff, who are responsible for studies and opinions that support decision making ([11]). This potential 
confrontation stands out within a context dominated by New Public Management, with a "growing appeal to the technical-scientific legitimisation of political decisions, the unprecedented valorisation of economic rationality" ([11], p. 120), marked by guidelines such as quality, assessment and audit, and which "have been revealing the potential clash of rationalities and legitimacies between political staff who take decisions and administrative staff who prepare studies, and technical opinions" ([11], p. 120).

In the words of this author, "Advisory services represent specialised elements of decision support" ([11], p. 136), being increasingly frequent the use of specialised and expert knowledge and knowledge, also called expertise, in order to substantiate and legitimise the discourses and policy decisions in education. In the exercise of political power, decision-makers increasingly resort to expert knowledge, in the form of opinions, studies, to legitimise the political decision. As the author states, alongside powers, there is knowledge. It is in this context, in the production of public policies in education, the complex relationships between knowledge and power stand out ([11]), assuming the internal advice a prominent position, in the words of the author:

"One of the ways to overcome the dilemmas above, seeking to ensure, simultaneously, expert knowledge and greater adherence to political agendas, technical autonomy as much as proximity to political power (...) thus reducing the distance between conception and decision, consists in the privileged recourse to internal advisory services, carried out by senior administration staff, offices or study groups" ([11]).

The author reinforces the idea, stating that internal advisory services have been increasingly central since knowledge, scientific knowledge and technical skills influence decision-making in politics and, in this way, we see an overlapping of management over governance.

It is in this context that is situated the central question that we follow: to study the influence of this group - internal advisors - in the Governance and Management of Portuguese Higher Education Institutions.

Our objective is to understand how internal advisors influence decision-making in the governance and management of Portuguese public HEls, and we will follow a qualitative research methodology. Through multiple case studies, we intend to analyse three HEls - two Universities, one of them with a foundational model, and one Polytechnic Institute - to understand how the same phenomenon occurs in three different contexts. To this end, we will interview actors at the central level of governance and management, rectors, president, administrators and advisors, and actors at the middle management level, faculty and organic unit (OU) directors and advisors.

\section{FINAL CONSIDERATIONS}

Given the literature on this topic, we consider that it is essential to study the influence of the advisors, given the increasing centrality that they assume, as they possess the power of experts, the power of knowledge, and their influence on policymakers.

Based on this research, we intend to reflect on and understand the role of internal advisors in Portuguese public HEls, identifying the specificity of the professional group of advisors and their relationships with other professional groups. According to the works of authors such as Whitchurch ([16], [17]), the nature of the work of professional staff has been redefined, and the contribution of this group of professionals can be maximised.

At the end of this research, we intend to understand how advisory services can improve the governance and management of HEls, as a promoter of approximation and mediation between knowledge and power ([11]), contributing to this area of knowledge.

\section{REFERENCES}

[1] A. Amaral, "Managerialismo e Governação das Instituições do Ensino Superior em Portugal", In Conselho Nacional de Educação, Formas de governo no ensino superior, pp. 33-49, 2004. https://www.cnedu.pt/content/antigo/files/pub/FormasGovenoEnsinoSuperior/5CasoPortugues.html

[2] R. Santiago, A. Magalhães, T. Carvalho, O Surgimento Do Managerialismo No Sistema De Ensino Superior Português. Coimbra: FUP-CIPES, 2005. 
[3] A. Veiga, A. M. Magalhães, S. Sousa, F. M. Ribeiro, A. Amaral, A Reconfiguração da Gestão Universitária em Portugal. Educação, Sociedade \& Culturas, 41, 7-23, 2014. https://www.fpce.up.pt/ciie/sites/default/files/ESC41_A_Veiga_et_al_.pdf

[4] A. Amaral \& A. Magalhães, O conceito de stakeholder e o novo paradigma do ensino superior. Revista Portuguesa de Educação, 13 (2), 07-28, 2000.

[5] A. Magalhães, A. Veiga, A. Amaral, The changing role of external stakeholders: from imaginary friends to effective actors or non-interfering friends. Studies in Higher Education, 43(4), 737-753, 2018. https://doi.org/10.1080/03075079.2016.1196354

[6] J. Pedrosa (Ed.), H. Santos, M. Mano, T. Gaspar, Novo Modelo de Governança e Gestão Das Instituições De Ensino Superior Em Portugal: análise dos usos do modelo em instituições públicas. CNE; Universidade de Aveiro e Fundação Calouste Gulbenkian. 2013. http://www.cnedu.pt/pt/noticias/cne/49-estudo-cne-sobre-o-rjies

[7] T. Carvalho \& P. Videira, Losing autonomy? Restructuring higher education institutions governance and relations between teaching and non-teaching staff. Studies in Higher Education, 44 (4), $762-$ 773, 2017. https://www.tandfonline.com/doi/full/10.1080/03075079.2017.1401059

[8] T. Carvalho \& S. Diogo, Exploring the relationship between institutional and professional autonomy: a comparative study between Portugal and Finland. Journal of Higher Education Policy and Management, 2017. https://doi.org/10.1080/1360080X.2018.1395916

[9] I. R. Dobson, 'Them and Us' - General and Non-General Staff in Higher Education. Journal of Higher Education Policy and Management, 22 (2), 203-210, 2010. https://doi.org/10.1080/713678142

[10] L. C. Lima, Abordagem político-organizacional da assessoria em educação. In J. A. Costa, A. NetoMendes \& A. Ventura (Eds.), A assessoria na educação em debate (pp. 13-30). Aveiro: Universidade de Aveiro, 2007.

[11] L. C. Lima, Assessoria, saberes e poderes na produção de políticas em educação. In Administração escolar: estudos. Porto: Porto Editora, 2011.

[12] UNESCO, "Rethinking Education: Towards a Global Common Good?", 2015. https://unevoc.unesco.org/e-forum/RethinkingEducation.pdf

[13] Lei n. ${ }^{\circ}$ 62/2007, de 2007-09-10, Regime Jurídico das Instituições do Ensino Superior, Diário da República n. 174/2007, Série I de 2007-09-10, 2007.

[14] R. D. Baltaru, Do non-academic professionals enhance universities' performance? Reputation vs. organisation, Studies in Higher Education, 44:7, 1183-1196, 2019. https://doi.org/10.1080/03075079.2017.1421156

[15] J. Szekeres, Professional staff carve out a new space. Journal of Higher Education Policy and Management. 33(6), 679-691, 2011. https://doi.org/10.1080/1360080X.2011.621193

[16] C. Whitchurch, Shifting Identities and Blurring Boundaries: the Emergence of Third Space Professionals in UK Higher Education. Higher Education Quarterly, 62: 377-396, 2008. https://doi.org/10.1111/j.1468-2273.2008.00387.x

[17] C. Whitchurch, "The Rise of the Blended Professional in Higher Education: A Comparison between the UK, Australia and the United States". Higher Education 58(3): 407-418. 2009. https://doi.org/10.1007/s10734-009-9202-4

[18] D. Sebalj, A. Holbrook, S. Bourke, The rise of 'professional staff' and demise of the 'non-academic': a study of university staffing nomenclature preferences. Journal of Higher Education Policy and Management. 34(5), 463-472, 2012. https://doi.org/10.1080/1360080X.2012.715994

[19] C. Whitchurch, The changing roles and identities of professional managers in UK higher education, Perspectives: Policy and Practice in Higher Education, 11:2, 53-60, 2007. https://doi.org/10.1080/13603100701259022

[20] J. D. Segóvia, "Asesoría educativa: modelos y processos", in Costa, J. A. et al. (2007) A Assessoria em Educação em Debate. Aveiro: Universidade de Aveiro, 2007.

[21] J. D. Segóvia, "Comprender y redireccionar las prácticas de asesoría", Revista iberoamericana de educación, 54, 65-83, 2010. 
[22] J. Laage-Thomsen, Professional expertise in policy advisory systems: How administrators and consultants built behavioral insights in Danish public agencies. Public Admin. 2021; 1- 16, 2021. https://doi.org/10.1111/padm.12725

[23] D. Saint-Martin, The New Managerialism and the Policy Influence of Consultants in Government: An Historical-Institutionalist Analysis of Britain, Canada and France. Governance, 11: 319-356, 1998. https://doi.org/10.1111/0952-1895.00074

[24] C. Leite, Para uma Escola Curricularmente Inteligente. Porto: Edições Asa, 2003.

[25] F. M. Bexiga, Assessoria(s) e ensino básico público: o ser e o fazer. In J. A. Costa, A. Neto-Mendes, \& A. Ventura (Eds.), A assessoria na educação em debate (pp. 81-89). Universidade de Aveiro, 2007.

[26] P. Block, Consultoria infalível. Um Guia Prático, Inspirador e Estratégico. São Paulo: M. Books, 2013. 